\title{
Analysis Of Quality Of Services, Relational Marketing And Handling Switching Cost As A Force Marketing To Improve Bank Customers's Loyalty In West Surabaya
}

\author{
Woro Utari ${ }^{1}$ and Mei Indrawati ${ }^{2}$ \\ \{woro.utari@yahoo.co.id ${ }^{1}$, meiindrawati@uwp.ac.id ${ }^{2}$ \} \\ Universitas Wijaya Putra, Surabaya, Indonesia ${ }^{1,2}$
}

\begin{abstract}
This study aims to examine and analyze the influence of service quality, Relational Marketing and Handling Switching Cost as a Marketing Force for Banking in Increasing Bank Customer Loyalty in West Surabaya. The unit of analysis in this study is the Government and Private Bank customers in West Surabaya. Respondents in this study were 125 people who were determined by Quota Sampling, while the sampling technique was Accidental Sampling. Data is collected using a questionnaire distributed to customers who are used as respondents. Then the data was analyzed using statistical aids (SPSS 22). The quality of service in Government and private banks in West Surabaya is good, but still needs to be improved. Relational marketing carried out by the bank is in line with customer expectations. Handling switching costs in banks are already good so there is a reluctance of customers to move. Service quality has a significant effect on customer loyalty, as well as Relational Marketing and handling switching costs have a significant effect on loyalty. The rapid development of the banking world has resulted in intense competition between banks. Therefore each bank strives to retain its customers through efforts to increase customer loyalty. Customer loyalty is a banking power in increasing its marketing. One of the efforts made by banks in increasing loyalty is to provide satisfaction through good service quality and good marketing relationships.
\end{abstract}

Keyword: Quality od Service, Relational Marketing, Handling Switching Cost

\section{Introduction}

The development of the banking world today is very fast, this is indicated by the increasing number of new bank banks that are emerging, not only conventional private banks, credit banks and Islamic banks but also the entry of foreign banks.

Service is one of the satisfying tools of human needs, but customer service in banks has its own characteristics that are different from goods products (Utari 2014). One thing that distinguishes it from goods, as stated by Gasperz in Tangkilisan (2005), is that the output is formless (intangible output), not standardized, and cannot be stored in inventory but can be consumed directly during production. 
Good service quality in the long run will generate loyalty, this will certainly reduce development costs, increase profitability and market share (China, 1990; Daniel, 1992; Synchan, 1990) in Woro (2004).

Quality of service is important in an effort to retain customers besides that a good relationship with customers also plays an important role in the success of a service business. Maintaining customers not to move to other banks is also an effort that must be made by the bank. One way that banks do in an effort to retain customers is by handling switching costs. The transfer of customers from one bank to another will greatly affect the productivity and capability of the bank.

The fundamental problem in the banking sector is the increasing number of banks in Indonesia which have an impact on the increasingly tight competition between banks. Thus the more consumers choose banking services, so the easier it is for customers to move from one bank to another.

Moving behavior can also be influenced by competitive situations, as the results of Jones and Sasser's research, as quoted by Srinivasan (1996: 27-28), conclude that a high competitive situation causes consumers to move high, while the competitive situation is low, consumers' tendency to move is also low. High competition areas include commodity goods (low differentiation), customer indifference, many substitute products available, and the cost of switching cheaply.

Based on the above thoughts, it is necessary to analyze the efforts made to increase the loyalty of bank customers in Surabaya. The purpose of this study is to describe service quality, relational marketing, handling switching and bank customer loyalty in West Surabaya, to test and analyze the effect of service quality, relational marketing and handling switching on bank customer loyalty in West Surabaya.

\section{Literature Review}

\subsection{Service Quality}

According to Tjiptono (2015), the quality of a service is the difference between the services provided and those expected by customers. In this case the assessment of the quality of services is determined by the service user. Parasuraman et al. (1998), states that perceived quality is consumer judgment about superiority or superiority of a entity. Quality definition here is that quality is a form of attitude, and is related but not the same as satisfaction, which is also produced by a comparison between expectations and perceptions of performance. According to James (2005), satisfaction is determined by consumer expectations and perceptions. Service quality has been conceptualized as the difference between customer expectations and actual performance of service providers (Theory of Gap).

According to Tjiptono (2015), the way consumers or customers assess the dimensions of service quality in the service sector is reliability. Promises are kept in accordance with the proper performance, such as productivity, service quality that meets existing standards, timeliness, accurate service, and no defects in the process. All performance is accompanied by responsiveness or power to respond to customer needs.

\subsection{Relational Marketing}

Kotler (2000) states that Relational Marketing in addition to building relationships with consumers is also built on satisfying long-term relationships with other key parties such as: suppliers, suppliers and others to maintain their long-term preferences and business. The main 
function of relational marketing is to cover all the steps that companies take to get to know and serve their customers well.

Relationship quality is the customer's perception of how well the entire relationship can meet customer expectations, predictions, goals and desires for the relationship, Jarvelin and Lehtinen (1996),

Gummeson (1987) identified two measures of relationship quality, namely: professional relations and social relations. Halmund (2001) proposes 3 different types of views of quality in a business relationship, namely technical aspects (relating to the core offerings of a relationship), social aspects (relating to the types of social transactions that vary for the level of individuals and companies) and economic aspect (related to cost-benefit).

Bruhn (2003) asserts that relational marketing (marketing relationship) is related to how a company is able to build familiarity with its customers. To be able to build a close relationship, a company must pay attention to two main dimensions, namely trust. Trust, an effort to build trust with consumers, which consists of three attributes, namely: Harmony, Acceptance, Participation simplicity, Familiarity. Zeithaml et al. (1996) stated that the ultimate goal of the company's success in establishing customer relations is to form strong customer loyalty.

\subsection{Handling Switching Cost}

According to Aaker (1997) there are levels of customer satisfaction and customer loyalty that are affected by the calculation of profit and loss. This group thinks of transition costs such as time, money, or risk. If the transition costs are higher than the benefits obtained, this group is loyal to the brand. However, if the transitional benefits outweigh the transitional costs, this group will change brands.

According to research conducted by Reinartz and Kumar in Keiningham et al. (2005), it was not found that loyal consumers would be willing to pay high prices from suppliers they already knew. Even in a study in the business market, it was revealed that old customers actually paid 5 to 7 percent cheaper than new customers. In other words, older customers pay more often and don't want to pay a higher price.

In such conditions, the sensitivity in controlling costs for switching costs to other banks is a consideration in choosing a bank, Utomo (2008). Costs that will be borne by the customer when switching to another bank (handling switching costs), especially for productive credit customers, namely: bank administration fees, credit proposals, higher interest costs in other banks, binding fees for guarantees and transportation costs.

\subsection{Customer Loyalty}

Loyalty is a favorable attitude towards a brand in addition to buying it repeatedly (Day, 1969); a relationship between the attitude relative to an entity and repeating the subscription (Dick and Basu, 1994). A situation if repeated purchases are followed by psychological ties (Jarvis and Wilcox, 1977); and the purpose and treatment of repetition of purchases (Peter et al, 1990).

Customer loyalty, a key intermediary variable that explains customer survival (Pritchard and Howard, 1997), considers the possibility of returns / benefits for customers, makes business referrals, provides strong word of mouth, as well as providing references and publicity (Bowen and Shoemaker, 1998 )

Understanding customer loyalty according to Kotler (2000) is:

"The long term success of a particular brand is not based on consumer who purchases it only once, but on the number who become repeat purchase".

According to Griffin (1996) characteristics of loyal customers include: Making regular purchases, buying outside the product or service line, rejecting products or services from other 
companies, immune to the attractiveness of competitors, attracting new customers to the company, weaknesses or shortcomings will be notified to company.

According to Schnaars in Tjiptono (2001), there are four possible types of relationships between customer satisfaction and customer loyalty: failures, forced loyalty, defectors, and successes, so satisfaction is no longer an intervening variable towards customer loyalty.

According to Roberts (2003), in shaping customer loyalty banks are thought to be directly influenced by perceptions of the marketing mix. Or before entering the loyal stage, first through 3 behaviors, namely cross selling (use of several products offered by the bank), word of mouth (willingness to provide recommendations on bank services to other parties) and retransaction commitment (commitment to repeat transactions).

\subsection{Hypothesis}

Based on the description on the theoretical basis and conceptual framework, the following hypothesis formulations are made Service quality, relational marketing and handling switching costs partially have a significant effect on customer loyalty

\section{Methode}

This research is an explanatory research, namely research which aims to explain the relationship between two independent variables or more to the dependent variable. The population in this study were all bank customers in western Surabaya, samples were taken using sampling techniques with accidental sampling method by determining the sample quota sampling. Furthermore, the data were analyzed using SPSS 22 to determine the effect of free vafiabel on the dependent variable.

To assess the validity of the measuring instrument used is the correlation formula proposed by Pearson known as the product moment correlation formula as follows:

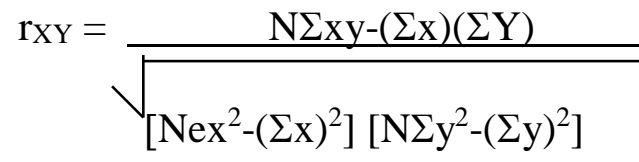

Description: $\mathrm{r}=$ correlation coefficient between variables $\mathrm{x}$ and $\mathrm{y}$

$\mathrm{N}=$ number of samples

$\mathrm{x}=$ score of each item

$\mathrm{y}=$ number of scores for each item

Conditions:

If the coefficient of validity $r$ count $>r$ table then the item is valid

This analysis is used to prove the correlation between service quality (independent variable) and customer satisfaction (dependent variable). The general equation of the multiple regression correlation line is (Suharsimi Arikunto, 1998)

$$
\mathrm{Y}=\mathrm{bo}+\mathrm{b} 1 \mathrm{X} 1+\mathrm{b} 2 \mathrm{X} 2+\mathrm{b} 3 \mathrm{X} 3+\mathrm{e}
$$

Information : 
$\mathrm{Y}=$ Customer / customer loyalty

$\mathrm{X} 1$ = Service Quality

X2 = Relational Marketing

X3 = Handling Switching Cost

Bo $=$ Regression line constants

$\mathrm{b}=$ Coefficient of change of $\mathrm{X}$ to $\mathrm{Y}$

After the price of bo, b1, b2 and b3, the equation of the regression line will be obtained, the line that states the relationship between the variables.

\section{RESEARCH RESULT}

Characteristics of Respondents based on education level

The level of education shows social class, the higher the education, the higher the social class. The following is described regarding the characteristics of bank customers based on education level.

Table 4.1. : Characteristics of respondents based on education level

\begin{tabular}{|l|l|l|l|}
\hline $\begin{array}{l}\text { Tingkat } \\
\text { Pendidikan }\end{array}$ & $\begin{array}{l}\text { Jumlah } \\
(\boldsymbol{\%})\end{array}$ & Pekerjaan & $\begin{array}{l}\text { Jumlah } \\
(\boldsymbol{\%})\end{array}$ \\
\hline SMP & $16,0 \%$ & Entrepreneur & $12,0 \%$ \\
\hline SMA & $36,0 \%$ & Employees & $33,0 \%$ \\
\hline DIPLOMA & $11,0 \%$ & $\begin{array}{l}\text { Government } \\
\text { Employees }\end{array}$ & $25,0 \%$ \\
\hline SARJANA & $25,0 \%$ & ABRI / TNI & $12,0 \%$ \\
\hline & & Student & $18,0 \%$ \\
\hline Total & $100,0 \%$ & Total & $100,0 \%$ \\
\hline
\end{tabular}

Source: Primary Data processed, 2018

Based on the table above, it is known that the bank customers who were respondents were mostly high school and undergraduate education, with 36 
percent of respondents having high school education and as many as 25 percent of respondents having undergraduate education, both S1, S2 and S3.

A person's job will influence someone's decision to save. The results of the study showed that as many as 33 percent of customers who were respondents worked as private employees, and as many as 25 percent.

\section{STATISTIC ANALYSIS}

Description of Service Quality Dimensions

The results showed that the comfort of the service room was very good and as many as 57 percent of respondents stated that the comfort of the service room was good. With regard to on line equipment and technology, it shows that as many as 58 percent of respondents state that on line equipment and technology are good, the availability of ATMs in some places is very adequate, making it easier for customers to make transactions through ATMs.

Description of Relational Marketing Variables

In general, it can be said that the relational infrastructure at the Bank in West Surabaya is good. This can be seen from the results of the questionnaire related to the harmonious relationship between the customers and bank employees who have been very good. Besides that Relational Marketing is also shown by the results of a questionnaire about Acceptance and responsiveness of Customer Service Officers who are already good, Friendliness / Familierity The sympathetic attitude of employees is very good,

\section{DESCRIPTION OF HANDLING SWITCHING COST}

One of the efforts made by banking companies is to maintain customers / customers by strengthening handling switching costs. The more 
accurate handling switching costs, the stronger the effort to maintain customer loyalty.

Based on the results of the study it is known that the cost of moving banks is very good, the affordability of access in completing transactions is also an indicator of handling switching costs. The results showed that affordability of access in completing transactions was good. One effort to retain customers by providing security guarantees to customers. The results of the research show that the Bank can be trusted to guarantee customer money, meaning that the bank provides security guarantees for the funds deposited in the bank.

Accuracy of Transaction records is very important for a customer, especially in the banking sector. The results showed that the accuracy of the transaction records was good.

\section{DESCRIPTION OF VARIABLE CUSTOMER LOYALTY}

Customer loyalty is a condition where someone will repurchase this because they are satisfied with the service provided by the service provider. In this case customer satisfaction is derived from the quality of service. In theory, it is said that the better the quality of service, the higher customer satisfaction will be. Customer loyalty is important in an effort to retain customers.

Based on the results of the study it is known that customers of Government and Private banks in West Surabaya include customers who have high loyalty. This is indicated by the number of customers who always make transactions at the bank, besides that the customer always delivers positive things about the bank.

Customers also always recommend to others to use the bank. Loyal customers will always increase the amount of funds they hold because they trust the bank. One characteristic of loyal customers is always influencing other people to join. 


\section{Results of inferential statistics}

Furthermore, after obtaining data on service quality, to find out the effect of service quality, relational marketing and handling switching costs on customer loyalty, we used statistical analysis. Based on the results of the analysis using SPSS the following values are obtained:

Table:

Results of Regression Analysis using SPSS 10

\begin{tabular}{|l|l|l|l|l|l|}
\hline \multirow{2}{*}{} & \multicolumn{2}{|l|}{$\begin{array}{l}\text { Unstandardized } \\
\text { coefficients }\end{array}$} & $\begin{array}{l}\text { Standardiz } \\
\text { ed } \\
\text { coefficients }\end{array}$ & \multirow{2}{*}{$\mathrm{t}$} & \multirow{2}{*}{ Sig. } \\
\cline { 2 - 5 } & & Std. Error & & & \\
\hline $1 \quad$ (Constant) & .190 & & 4.322 & .000 \\
Kualitas & .057 & .429 & 4.832 & .000 \\
Pemsaran Relasi & & .054 & .372 & 3.274 & .002 \\
Handling & .055 & .216 & 2.041 & .004 \\
\hline
\end{tabular}

Source: Results of Data Analysis in Appendix, 2018

From the table above, a regression equation can be made as follows

$$
\mathrm{Y}=0.820+0.439 \mathrm{X} 1+0.384 \mathrm{X} 2+0.273 \mathrm{X} 3
$$

The equation can be explained that:

Service quality has an influence on customer loyalty of 0.439 , while relational marketing has an influence on customer loyalty of 0.384 and handling switching costs have an influence on customer loyalty of 0.273 .

Furthermore, to test the hypothesis that service quality, relational marketing and handling switching costs partially have a significant effect on customer loyalty, the $t$ test is used. the results of the analysis using the $t$ test the value of $t$ calculated for service quality is 4,832 , with a significance level of 0,000 . The value of $\mathrm{t}$ count for relational marketing is 3.274 with a significance level of 0.002 and the calculated $t$ value for handling switching cost is 2.041 with a significance level of 0.004 . 
Based on the table above, it can also be said that the value of $t$ calculated for service quality is 4,832 with a significance level of 0,000 which has the highest $\mathrm{t}$-value and the largest regression coefficient. This means that service quality has the greatest influence on customer loyalty.

Improvement of services in physical form can be done through structuring of buildings, parking lots etc. Customers will feel comfortable if the bank has a large parking lot. A comfortable waiting room, the physical appearance of the bank will also be able to improve service quality.

Furthermore, to find out the effect of service quality, relational marketing and handling switching cost, simultaneous analysis was used by using the F test. The results of the analysis of Variants as follows:

Table:

Results of Variant Analysis (ANOVA)

\begin{tabular}{|cl|l|l|l|l|l|}
\hline \multicolumn{2}{|c|}{ Model } & $\begin{array}{l}\text { Sum of } \\
\text { Squares }\end{array}$ & Df & $\begin{array}{l}\text { Mean } \\
\text { Square }\end{array}$ & F & Sig. \\
\hline $1 \quad$ Regression & 3.109 & 3 & 1.036 & 50.541 & $.000^{\mathrm{a}}$ \\
& $\begin{array}{l}\text { Residual } \\
\text { Total }\end{array}$ & 1.969 & 96 & .021 & & \\
\hline
\end{tabular}

Based on the results of data analysis using SPSS as in the table above it is known that the value of $\mathrm{F}$ count is 50,541 with a significance level of 0,000 which means that service quality, relational marketing and handling switching cost together have a significant effect on customer loyalty. This means that if there are improvements in service quality, relational marketing and handling switching costs it will increase customer loyalty. The results of data analysis show that the quality of service provides a significant influence on customer loyalty. Therefore it is necessary for banks to improve service quality based on the dimensions of service quality. 
Furthermore, to find out the magnitude of the contribution of service quality variables, relational marketing and handling switching costs to customer loyalty can be seen from the coefficient of determination. The results of data analysis show that the coefficient of determination is 0.612 which means $61.2 \%$ loyalty satisfaction is explained by service quality, relational marketing and handling switching costs while the rest is explained by other variables outside of this study.

Discussion

Based on the results of research and data analysis, things can be described as follows:

Quality of service is an important factor in an effort to increase customer loyalty through customer satisfaction. Service quality in this case can be seen from the service dimension which consists of physical evidence, reliability, responsiveness, empathy and assurance. Physical evidence will determine or influence the appearance which will ultimately affect the quality of service. In theory it can be said that service quality will affect satisfaction. Improvement of services in physical form can be done through structuring of buildings, parking lots etc. Customers will feel comfortable if the bank has a large parking lot. A comfortable waiting room, the physical appearance of the bank will also be able to improve service quality.

Relational marketing is an activity related to the relationship between customers and employees / bank officers. Relational marketing has a positive influence on customer loyalty. The better the relational marketing, the higher customer loyalty will be. The results of the study indicate that relational marketing has a positive and significant influence on customer / customer loyalty. This is indicated by the value of $\mathrm{t}$ count for relational marketing which has a significance level of less than 0.05 . 
Relational marketing is an important factor in increasing customer loyalty. The results of the study show that the better the harmony of the relationship between the customer and the bank employees will give satisfaction to the customer. The better the acceptance and responsiveness of the Customer Service Officer, the more satisfied the customer will be. Besides that Hospitality / Familierity The sympathetic attitude of employees will also greatly influence customer loyalty. The better the friendliness / familiarity or sympathetic attitude, the more loyal the customer will be.

Handling Switcing Cost is one of the determinants of customer loyalty. The better handling switching costs, the more loyal customers will be. The results of this study indicate that partially handling switching has a positive and significant effect on customer loyalty.

The easier access to access in completing transactions will be more loyal customers. One effort to retain customers by providing security guarantees to customers, the better the security, the more loyal customers will be. Besides that customer trust in the security of funds in the bank is also an important factor in increasing customer loyalty.

Accuracy of records Transactions are very important for a customer, especially in the banking sector, the more accurate the transaction records, the higher the customer's trust, the higher customer loyalty.

Conclusion

Based on the results of research and data analysis as in the description above can be concluded as follows:

Service quality, relational marketing and handling switching costs have a significant effect on customer loyalty of Government and Private Bank banks in West Surabaya. 
Service quality, relational marketing and handling switching costs partially have a significant effect on loyalty, this is indicated by the value of $t$ count for each variable that has a significance value of less than 0.05 . thus the hypothesis which states that the dimensions of service quality partially have a significant effect on customer satisfaction is proven true. Next to find out the magnitude of the influence of the free variable on the dependent variable seen from the coefficient of determination. Based on the results of data analysis it is known that the coefficient of determination is 0.612 which means that the dimensions of service quality have an influence of $61.2 \%$ on customer loyalty, the remaining $38.8 \%$ is influenced by other variables including image, price etc.

Based on the results of data analysis it is known that service quality has a dominant influence on customer loyalty because with physical evidence displayed by banks including buildings and waiting rooms has the most influence on customer satisfaction.

\section{Suggestion}

Based on the results of the research and analysis described above, suggestions can be given as follows:

Banks need to improve service quality, this is due to the highest quality of service. Efforts made by banks to improve service quality are by improving physical buildings, large parking lots, comfortable waiting rooms etc.

Besides that banking companies also need to improve relational marketing with customers.

\section{LITERATURE}

Aaker, and Kumar, 2001. Marketing Research., John Wiley, New York. 
Adam P.Heath \& Don Scott, 1998, “The Self-Concept and Image Congruence Hypothesis", European Journal of Marketing Vol.32 No.11/12.

Blakely, 1994, Planning Local Economic Development, Theory and Practice, 2nd edition, Sage Publication.

Brigham \& Daves, 2004, Intermediate Financial Management, 8th edition,South-Western USA.

Brown, Lisanne, Fond, Anne, Macintyre, Kate 2001, Measuring Capacity Building. Carolina Population Centre/ University of North Carolina, Chapel Hill.

Cronin and Taylor, 1982, Measuring service quality : a reexamination and extension, Journal of Marketing Vol. 56, July, pp. 55-68.

Culligan, 1994, Management Back to Basic, Prentice Hall International Inc., New Jersey.

Churchill and Suprenant, 1982; Oliver and De Sarbo, 1988; Spreng and Olshavsky, 1993, International Journal Of Bank Marketing, 16/2, $1998, p .53)$

Dowling, 1994, The self concept and image congruence hypothesis, European journal of marketing vol. 32, no. 11/12, MCB University Press.

Edralin, 1997, The New Local Governance and Capacity Building : A Strategic Approach, Regional Development Studies, Vol. 3, p.148150.

Evans, 1999. Customer Relationship Management : Creating The Customer- Centric Financial Services Organization. Lafferty Publications, Dublin Fitzsimmons,

Garcia-Zamor, Jean-Claude, (1985), Public Participation in Development Planning and Management : Cases from Africa and Asia, London : Westvoiew Press. 
Gerson, Richard, 1993. Measuring Customer Satisfaction. Crisp Publication, Inc

Gervey \& Swan, 1994, On the relationship between store image, store satisfaction and store loyalty, European journal of marketing, vol. 32, no.5/6 MCB Univercity Press.

Gronroos, 1990, Service management and marketing: Managing the Moment of truth in service competition, Lexington books, Lexington, MA.

Hayes, 1998. Measuring Customer Satisfaction : Survey Design, Use and Statistical Analysis Methods. ASQ Quality Press, Milwaukee.

Herzberg, 1988, Human Resource Management, Business skill express series, Irwin professional publishing \& mirror press.

Hill, Michael \& Peter Hupe, (2002), Implementing Public Policy : Governance in Theory and in Practice, London : Sage Publications.

Hothum, and Susanne. 1999. Customer Satisfaction Research. Institute of Service Management Studies.

Ivancevich, 2002, Building customer loyalty, Business skill express series, Irwin professional publishing \& mirror press.

J.A. and Fitzsimmons. 2001. Service Management : Operations, Strategy, and Information Technology. McGraw-Hill, Singapore

Kasey \& Wright, 1997, Towards A Framework For Managing Corporate Image, European Journal of marketing. Vol.31 No 5/6, MCB Univercity Press.

Kate, 2001, Measuring Capacity Building, Carolina Population

Centre/University of North Carolina, Chapel Hill. 
Kerlinger, 1990, Practical issue in structural modeling, Sociological methods and research 16 (1), 78-117. 